Research Article

\title{
Associated pseudoscorpions (Arachnida: Pseudoscorpiones) with waste heaps of Atta colombica (Guérin-Méneville, 1844) (Hymenoptera: Formicidae) in Panama
}

\author{
Pseudoescorpiones (Arachnida: Pseudoscorpiones) asociados con vertederos de Atta \\ colombica (Guérin-Méneville, 1844) (Hymenoptera: Formicidae) en Panamá
}

Ramy Jhasser Martínez ${ }^{1^{*}}$, Gabriel A. Villegas Guzmán³, Dora Isabel Quirós ${ }^{1,2}$ and Daniel Emmen ${ }^{1,2}$

${ }^{1}$ Laboratorio de Estudios Biológicos de Artrópodos, Vicerrectoría de Investigación y Postgrado, Universidad de Panamá, Ciudad de Panamá, Panamá. Facultad de Ciencias Naturales, Exactas y Tecnología, Universidad de Panamá, Ciudad de Panamá, Panamá. ${ }^{3}$ Laboratorio de Acarología, Departamento de Zoología Escuela Nacional de Ciencias Biológicas, Instituto Politécnico Nacional, Prolongación de Carpio y Plan de Ayala, S/N. Col. Santo Tomás, C.P. 11340 Ciudad de México, México.

\section{ZooBank: urn:lsid:zoobank.org:pub:BF31DF6F-4DAF-4E0E-A8CE-4990162DE455 https: / / doi.org/10.35249/ rche.47.1.21.06}

\begin{abstract}
Waste heaps of Atta are host to an extraordinary diversity of myrmecophiles insects and other arthropods. In this study, the presence of four species of pseudoscorpions is recorded in two Atta colombica waste heaps in the years 2016 and 2017. Two of these species, Cordylochernes scorpioides and Lustrochernes carolinensis are new records in waste heaps and except for the deutonymphs of $L$. carolinensis, the others all stages of post-embryonic development were present in the studied heaps, which could indicate that these two species carry out their entire life cycle in these waste mounds and live there permanently.
\end{abstract}

Key words: Ant nests; Atemnidae; Cheiridiidae; Chernetidae; symbiosis.

Resumen. Los vertederos de Atta albergan una extraordinaria diversidad de insectos mirmecófilos y otros artrópodos. Este estudio registra la asociación entre Atta colombica y cuatro especies de pseudoescorpiones recolectadas en dos vertederos en 2016 y 2017. Dos de estas especies, Cordylochernes scorpioides y Lustrochernes carolinensis son nuevos registros en vertederos, y con excepción de las deutoninfas de L. carolinensis, las demás etapas de desarrollo post-embrionario estuvieron presentes en los vertederos estudiados, lo que podría indicar que estas dos especies llevan a cabo todo su ciclo de vida en estos lugares viviendo allí permanentemente.

Palabras clave: Atemnidae; Cheiridiidae; Chernetidae; nidos de hormigas; simbiosis.

\section{Introduction}

Myrmecophily is a biological concept that describes casual or intimate associations of various organisms with ants (Rocha et al. 2020). It refers to mutualistic associations, though in its more general use the term may also refer to commensal or even parasitic interactions

Received 8 January 2021 / Accepted 3 February 2021 / Published online 26 February 2021

Responsible Editor: José Mondaca E. 
(Hölldobler and Wilson 1990; Hughes et al. 2008). Some arthropods have close associations with ant species, often living alongside the ants or within the ant colonies (Cushing 2012). Many species across diverse taxa thrive in large numbers in the ant waste heaps attracted by the enrichment of organic material, ideal climatic conditions, and constant supply of nutrients (Parmentier 2016). They may feed on the stored food supplies of ants or consume waste materials in the waste heaps, such as dead ants, dead larvae, or fungi growing in the nest while others are predatory on ant eggs, larvae, or pupae. Others benefit the ants by providing a food source for them (Hölldobler and Wilson 1990). This association is reported in several genera of isopods, pseudoscorpions, many spiders, mites, millipedes, and about 100 families of insects (Hölldobler and Wilson 1990). Underground refuse chambers are frequent in most Atta Fabricius, 1805 ants (Stahel and Geijskes 1939; Autuori 1947; Moser 1963), but some species dispose of their refuse material on a single waste heap above ground (Weber 1972) at a safe distance from the colony. These waste heaps are host to a high diversity of insects and other arthropods, among the most common being mites and staphylinid beetles (Rojas 1989; Hölldobler and Wilson 1990). One group of arachnids associated with waste heaps of Atta are pseudoscorpions, who are predominantly solitary animals that can live in the ground substratum, in the vegetation, or in both. Beier (1948) and Muchmore (1971) recognized six different categories of relationships between pseudoscorpions with other animals. One of them was the relationship established by those species found in the waste heaps of social insects such as ants (Christophoryová et al. 2017; Cervená et al. 2020).

Twenty-four records of associations with ant nests were found in 18 species of 16 genera and seven families of pseudoscorpions (Table 1). There are 10 records of associations with the genus Camponotus Mayr, 1861 while on Atta there are four records and only one species of pseudoscorpion related with $A$. colombica (Table 1 ).

Table 1. Reported pseudoscorpions associated with nests of ants.

\begin{tabular}{|c|c|c|c|}
\hline Family & Species & Host & Reference \\
\hline Atemnidae & $\begin{array}{l}\text { Paratemnoides nidificator } \\
\text { (Balzan) }\end{array}$ & Cephalotes atratus (L.) & Torres et al. 2018 \\
\hline Cheiridiidae & $\begin{array}{l}\text { Cryptocheiridium mairae } \\
\text { Bedoya-Roqueme \& Quirós- } \\
\text { Rodríguez }\end{array}$ & $\begin{array}{l}\text { Atta colombica (Guérin- } \\
\text { Méneville) }\end{array}$ & $\begin{array}{l}\text { Bedoya-Roqueme } \\
\text { \& Quirós- } \\
\text { Rodríguez } 2015\end{array}$ \\
\hline \multirow[t]{9}{*}{ Chernetidae } & $\begin{array}{l}\text { Allochernes deceuninckorum } \\
\text { Henderickx \& Vets }\end{array}$ & $\begin{array}{l}\text { Camponotus } \\
\text { (Tanaemyrmex) sylvaticus } \\
\text { (Olivier) }\end{array}$ & $\begin{array}{l}\text { Henderickx \& Vets } \\
2003\end{array}$ \\
\hline & $\begin{array}{l}\text { Allochermes wideri (C.L. } \\
\text { Koch) }\end{array}$ & $\begin{array}{l}\text { Formica Linnaeus, } 1758 \text { \& } \\
\text { Lasius Fabricius, } 1804\end{array}$ & $\begin{array}{l}\text { Leclerc \& Heurtault } \\
1979\end{array}$ \\
\hline & $\begin{array}{l}\text { Americhernes eidmanni } \\
\text { (Beier) }\end{array}$ & Atta Fabricius, 1804 & Harvey 1991 \\
\hline & Chernes vicinus (Beier) & Lasius fuliginosus (Latreille) & Cooreman 1947 \\
\hline & Incachernes mexicanus (Beier) & Atta mexicana (F. Smith) & $\begin{array}{l}\text { Reyes-Castillo \& } \\
\text { Hendrichs } 1975\end{array}$ \\
\hline & $\begin{array}{l}\text { Lustrochernes communis } \\
\text { (Balzan) }\end{array}$ & Camponotus rufipes (Fab.) & Beier 1970 \\
\hline & Marachernes bellus Harvey & Iridomyrmex Mayr & Harvey 1992 \\
\hline & & Iridomyrmex Mayr & Harvey 2015 \\
\hline & & $\begin{array}{l}\text { Anonychomyrma biconvexa } \\
\text { Clark }\end{array}$ & Harvey 1992 \\
\hline
\end{tabular}


Myrmochernes Tullgren, 1907 Camponotus maculatus Harvey 1994

(Fab.)

Camponotus rufipes (Fab.)

Acromyrmex lundii

(Guérin-Méneville)

Camponotus africanus

Newlands 1978

Santschi

Sphenochernes camponoti

Camponotus rufipes (Fab.)

Beier 1970

Beier

Xenochernes caxinguba Feio Acromyrmex lundii

Harvey 1994

(Guérin-Méneville)

Camponotus rufipes (Fab.)

\begin{tabular}{llll} 
Chthoniidae & $\begin{array}{l}\text { Pseudochthonius brasiliensis } \\
\text { Beier }\end{array}$ & Camponotus rufipes (Fab.) & Beier 1970 \\
& $\begin{array}{l}\text { Tridenchthonius mexicanus } \\
\text { Chamberlin \& Chamberlin }\end{array}$ & Atta mexicana (F. Smith) & $\begin{array}{l}\text { Reyes-Castillo \& } \\
\text { Hendrichs 1975 }\end{array}$ \\
\hline Ideoroncidae & Ideoroncus lenkoi Beier & Camponotus rufipes (Fab.) & Beier 1970 \\
\hline Olpiidae & $\begin{array}{l}\text { Pachyolpium crassichelatum } \\
\text { (Balzan) }\end{array}$ & Camponotus rufipes (Fab.) & Muchmore 1971 \\
& $\begin{array}{l}\text { Pachyolpium isolatum } \\
\text { (Chamberlin) }\end{array}$ & Labidus coecus (Latreille) & \\
\hline Withidae & $\begin{array}{l}\text { Nannowithius wahrmani } \\
\text { Beier }\end{array}$ & Messor semirufus (André) & Beier 1963 \\
\hline
\end{tabular}

From Panama, there have been reported associations of Pachyolpium Beier, 1931 and Lustrochernes Beier, 1932 pseudoscorpions with Labidus coecus and Eciton hamatum (Fabricius, 1782) ants respectively (Muchmore 1971). The status of the pseudoscorpions found in thenests of ground-living social insects is difficult to ascertain because most of the pseudoscorpion collections consist of only one or two specimens associated with other animals. There is no data on the frequency with which certain species associate with insects and there is no information about what pseudoscorpions do in ants' nests (Muchmore 1971; Hölldobler and Wilson 1990) and some of the recorded species of pseudoscorpions associated to ants might have simply landed accidentally in the mounds (Parmentier 2016). In this study, is recorded the presence of four species of pseudoscorpions in two Atta colombica waste heaps.

\section{Materials and Methods}

The study was carried out in the Parque Natural Metropolitano (PNM) that comprises an area of 270 ha located adjacent to a capital city $\left(8^{\circ} 59^{\prime} 28^{\prime \prime} \mathrm{N}-79^{\circ} 32^{\prime} 46^{\prime \prime} \mathrm{W}\right)$. It is characterized by shallow soils with presence of gravel, low natural fertility, and high susceptibility to pluvial erosion, a very humid climate, and an average temperature of $27^{\circ} \mathrm{C}$. During last 80 years the PNM has reverted from abandoned pasture to a secondary dry, deciduous, lowland in which there are 284 species of plants with 80 families and 228 genera (ANAM 2007)

Pseudoscorpions were collected in two waste heaps of Atta colombica in two years, 2016 (November) and 2017 (February). The sampling sites were approximately one kilometer apart and were selected for their accessibility and size of their waste heaps. At each site 
three samples of ant waste of approximately $300 \mathrm{~cm}^{3}$ each were collected $\left(900 \mathrm{~cm}^{3}\right.$ total per sampling site) separated $50 \mathrm{~cm}$ from each other to ensure that we captured representative diversity of the site. The samples were placed into labeled plastic bags (Rojas 1989) and transported to the Laboratory of Biological Studies of Arthropods at the University of Panama (LEBA-UP) where they were checked under the stereoscope to collect any visible pseudoscorpions, and then the material was placed in a Berlese funnel (Gabbutt 1970) to collect the rest of the specimens that were hidden. Pseudoscorpions were processed using Hoff's (1949) technique, modified following Wirth and Marston (1968). Organisms were measured in millimeters using Chamberlin's (1931) method, modified by Benedict and Malcolm (1977). The terminology follows Chamberlin (1931), Muchmore (1991), Harvey (1992) and Judson (2007). The specimens were deposited in the Museum of Invertebrates of the University of Panama.

\section{Results}

A total of 55 specimens were obtained from the samples collected from waste heaps of A. colombica in both sampling sites within the PNM in 2016 and 2017. These specimens belonged to three families, four genera and four species (Table 2). Only Lustrochernes carolinensis Muchmore, 1991 was collected in both years. Two of the species collected (Cryptocheiridium sp. and Paratemnoides nidificator Balzan, 1888) were represented by one male each. Nevertheless, the other two species (Cordylochernes scorpioides (Linnaeus, 1758) and Lustrochernes carolinensis)) were quite abundant in these two waste heaps of A. colombica when samples were taken.

Table 2. Species of pseudoscorpions associated to debris of Atta colombica in Parque Natural Metropolitano in Panama. $\mathrm{P}=$ protonymph, $\mathrm{D}=$ deutonymph, $\mathrm{T}=$ Tritonymph.

\begin{tabular}{|c|c|c|c|c|c|c|c|c|}
\hline Family & Species & q & 0 & $\mathrm{P}$ & $\mathrm{D}$ & $\mathrm{T}$ & Total & Date \\
\hline \multirow[t]{2}{*}{ Chernetidae } & Cordylochernes scorpioides (Linnaeus) & 1 & 4 & 1 & & 3 & 9 & 2-3-2017 \\
\hline & Lustrochernes carolinensis Muchmore & 17 & 13 & 2 & 3 & 8 & 44 & $\begin{array}{c}11-2-2016 \\
2-3-2017\end{array}$ \\
\hline Cheiridiidae & Cryptocheiridium sp. & & 1 & & & & 1 & $2-3-2017$ \\
\hline Atemnidae & Paratemnoides nidificator (Balzan) & & 1 & & & & 1 & 2-3-2017 \\
\hline
\end{tabular}

Except for the deutonymphs of C. scorpioides (Linnaeus, 1758) the other post-embryonic development stages of $C$. scorpioides and L. carolinensis were present in the studied waste heaps, which could indicate that these two species carry out their entire life cycle in these waste piles and might live there permanently (Table 2). L. carolinensis was observed feeding on staphylinides and $C$. scorpioides on mites during the sorting process under the stereomicroscope. The absence of C. scorpiodes, Cryptocheiridium and P. nidificator from the collection sites in 2016 could be due to inadequate sampling during the first year of study or evidence of an ecological succession occurring in these waste heaps. Additional and longer studies are needed to determine if there is a sequence in which pseudoscorpions arrive to these Atta waste piles.

\section{Discussion}

From de four species of pseudoscorpions (C. scorpioides, L. carolinensis, Cryptocheiridium sp., and P. nidificator) found in the waste heaps of A. colombica, one of the species ( $P$. nidificator) had already been previously recorded in nests of Cephalotes atratus ants (Table 
1). C. scorpioides and L. carolinensis are registered for the first time in ant nests. L. carolinensis is distributed around 100 meters or less above sea level, from North Carolina to Panama (Muchmore 1991; Martínez et al. 2019). This species has been found under the bark of Quercus L., Enterolobium cyclocarpum (Jacq.), Avicennia germinans (L.) L. and under the elytra of cerambycid and carabid beetles (Muchmore 1991; Martínez et al. 2019). C. scorpioides is distributed throughout the tropical forests of Central and South America living in decaying trees and it is frequently found under the elytra of cerambycid beetles (Beier 1948; Muchmore 1971; Zeh and Zeh 1991, 1992).

Despite the importance of leaf-cutting ants in natural ecosystems (Haines 1978) and in agricultural systems, waste management has received little attention (Hart and Ratnieks 2002). Unlike most leaf-cutting ants, which have underground waste dumps, the leafcutting ant $A$. colombica dumps waste in an external heap placed down-hill of foraging entrances of the nest. Large colony size results in large quantities of waste, including old fungus garden, culture medium, and dead workers (Weber 1972). Therefore, the constant supply of nutrients in these waste heaps may lead to an increase in the abundance and richness of soil biota, such as a diverse bacterial community (Lewin et al. 2016). As result, a large number of species across diverse taxa may feed on this organic material and a complex trophic web might gradually evolve from producers to predators of different levels. This creates a suitable and attractive environment for the establishment of a high diversity of other arthropods (Hölldobler and Wilson 1990).

Therefore, the environmental conditions of these waste heaps and the presence of food necessary for their development are the probable reasons for the presence of pseudoscorpions there. These arachnids feed on mites, springtails, beetle larvae and other small arthropods (Muchmore 1971; Kistner 1979; Hölldobler and Wilson 1990; Harvey 1992). There are 18 species of pseudoscorpions associated with ant nests, although the nature of their relationships with ants has not been clarified, many of these records are considered debatable, however in this study nine individuals of C. scorpioides and 44 of L. carolinensis were found including stages of their post-embryonic development. This indicates that these organisms live permanently in these ant waste heaps and carried out their entire life cycle there, therefore we do not consider their presence circumstantial but rather well-established although additional studies are necessary to demonstrate it. The presence of only one specimen of Cryptocheiridium Chamberlin, 1931 and P. nidificator (Balzan, 1888) in the waste heaps could be considered accidental, fortuitous, or temporary (Harvey 2015). The species $P$. nidificator deserves a special mention, since it lives in rough barks of trees in groups of 2 to 175 individuals and sometimes more than 200 organisms (Tizo-Pedroso and Del-Claro 2007; Del-Claro and Tizo-Pedroso 2009) and perhaps was in the surroundings when samples were taken. This record of its presence in the waste heap of $A$. colombica is one of the earliest. The genus Cryptocheiridium has already been recorded in nests of $A$. colombica (Bedoya-Roqueme and Quirós-Rodríguez 2015), so it may be a common inhabitant of these micro habitats.

The fact that some pseudoscorpions were observed feeding on some small arthropods such as mites and staphylinides that coexist in the waste heap is a preliminary evidence that these external dumpsters may be envisioned as collections of species that are organized into food chains and webs in which each species is a consumer of resources and is itself a resource for other consumers (Schmitz et al. 2008).

In this preliminary study, there were no observations of aggressive responses from any member of the $A$. colombica colony towards pseudoscorpions or other arthropods. The waste heap placement down-hill, seems to reduce interactions between Atta waste transporters and the waste heap community.

The relationships established by the pseudoscorpions with different organisms must be studied to understand how they are carried out and what factors affect them, especially 
in nests where they share micro habitats with a wide variety of species with which they are related to in many ways.

Waste heaps of Atta nests and the communities thriving in there may have an important impact on neotropical rainforest because of their effect in the soil and between ants and pseudoscorpions, therefore more research needs to be done to answer the following questions:

- How long arthropods remain in abandoned Atta nests after the colony moves to another site?

- What is the role of these waste heaps communities in the health of soil ecosystems in tropical rainforests?

- What is the degree of dependence between the organisms that live in these waste heaps and the continuous supply of organic matter from the nest?

- How ecological succession occurs in these waste heaps?

- What benefits if any, ants derive from the community that thrives in the waste heap?

\section{Author contributions}

RJM, GAVG, DIQ, and DE wrote the first draft and identified the collected material. Collaborated in writing the manuscript and corroborating the identification of the pseudoscorpion.

\section{Acknowledgements}

The authors thank the Vicerrectoría de Investigación y Postgrado of the Universidad de Panamá for the funds granted to the project "Biodiversidad de Pseudoscorpiones (Arachnida: Pseudoscorpiones) en la República de Panamá" with the code CEIP-01-04-05-2018-05. In addition to Prof. Edwin Domínguez and Jeraldine Vergara for the collection of the specimens.

\section{Conflict of interest}

The authors declare that there is no conflict of interest.

\section{Literature Cited}

ANAM (2007) Resumen Ejecutivo del Plan de Manejo del Parque Natural Metropolitano, Panamá. 33 pp.

Autuori, M. (1947) Contribuicao para o conhecimento da saúva (Atta spp. IV). O sauveiro depois da primeira revoada (Atta sexdens rubripilosa Forel, 1908). Arquivos do Instituto Biologico, 18: 39-70.

Beier, M. (1948) Phoresie und phagophilie bei pseudoscorpionen. Österreichische Zoologische Zeitschrift, 1: 441-497.

Beier, M. (1963) Die Pseudoscorpionen-Fauna Israels und einiger angrenzender Gebiete. Israel Journal of Zoology, 12: 183-212.

Beier, M. (1970) Myrmecophile Pseudoskorpione aus Brasilien. Annalen des Naturhistorischen Museums in Wien, 74: 51-56.

Bedoya-Roqueme, E. and Quirós-Rodríguez, J.A. (2015) Primer reporte del género Cryptocheiridium (Pseudoscorpiones: Cheiridiidae: Cheiridiinae) en Colombia. Revista Colombiana de Ciencia Animal, 7(1): 11-18. https: / / doi.org/10.24188/ recia.v7.n1.2015.292

Benedict, E.M. and Malcolm. D.R. (1977) Some garypoid false scorpions from Western North America. (Pseudoscorpionida: Garypidae and Olpiidae). Journal of Arachnology, 5: 113-132. 
Červená, M., Krajčovičová, K. and Christophoryová, J. (2020) Pseudoscorpions (Arachnida: Pseudoscorpiones) in the nests of Formica ants in Slovakia Štúriky (Arachnida: Pseudoscorpiones) v hniezdach mravcov rodu Formica na Slovensku. Klapalekiana, 56: 205-212.

Chamberlin, J.C. (1931) The arachnid order Chelonethida. Stanford University Pubications. Biological Sciences, 7(1): 1-284.

Christophoryová, J., Grulá, D. and Krajčovičová, K. (2017) New records of pseudoscorpions (Arachnida: Pseudoscorpiones) associated with animals and human habitats in Slovakia and the Czech Republic. Arachnologische Mitteilungen, 53: 67-76.

Cooreman, J. (1947) Chernes lasiophilus n. sp., Chélonète myrmécophile de Belgique. Bulletin du Musée Royal d'Histoire Naturelle de Belgique, 23(28): 1-6.

Cushing, P. (2012) Spider-ant associations: An updated review of myrmecomorphy, myrmecophily, and myrmecophagy in spiders. Psyche: A Journal of Entomology, 2012: 1-23. https: / / doi.org/10.1155/2012/151989

Del-Claro, K. and Tizo-Pedroso, E. (2009) Ecological and evolutionary pathways of social behavior in pseudoscorpions (Arachnida: Pseudoscorpiones). Acta Ethologica, 12: 13-22.

Gabbutt, P.D. (1970) Sampling problems and the validity of life history analyses of pseudoscorpions. Journal of Natural History, 4: 1-15.

Haines, B.L. (1978) Element and energy flows through colonies of the leaf-cutting ant Atta colombica in Panama. Biotropica, 10: 270-277.

Hart, A.G. and Ratnieks, F.L. (2002) Waste management in the leaf-cutting ant Atta colombica. Behavioral Ecology, 13(2): 224-231.

Harvey, M.S. (1991) Catalogue of the Pseudoscorpionida. Manchester University Press: Manchester. USA. 726 pp.

Harvey, M.S. (1992) A new genus of myrmecophilous Chernetidae from southern Australia (Pseudoscorpionida). Records of the Western Australian Museum, 15(4): 763775.

Harvey, M.S. (1994) Redescription and the systematic position of the Brazilian genus Xenochernes Feio (Pseudoscorpionida: Chernetidae). The Journal of Arachnology, 22: 131-137.

Harvey, M.S. (2015) A review of the taxonomy and biology of pseudoscorpions of Nannowithius and Termitowithius (Pseudoscorpiones, Withiidae), inquilines of social insects. The Journal of Arachnology, 43(3): 342-352.

Henderickx, H. and Vets, V. (2003) A new myrmecophilous Allochernes (Arachnida: Pseudoscorpiones: Chernetidae) from Catalunya, Spain. Zootaxa, 366(1): 1-10. https: / / doi.org/10.11646/ zootaxa.366.1.1

Hoff, C.C. (1949) The pseudoscorpions of Illinois. Bulletin of the Illinois Natural History Survey, 24: 407-498.

Hölldobler, B. and Wilson, E. (1990) The Ants. Cambridge, Manchester: Harvard University Press. USA. 712 pp.

Hughes, D.P., Pierce, N.E. and Boomsma, J.J. (2008) Social insect symbionts: evolution in homeostatic fortresses. Trends in Ecology E Evolution, 23: 672-677.

Judson, M.L.I. (2007) A new and endangered species of the pseudoscorpion genus Lagynochthonius from a cave in Vietnam, with notes on chelal morphology and the composition of the Tyrannochthoniini (Arachnida, Chelonethi, Chthoniidae). Zootaxa, 1627: 53-68.

Kistner, D.H. (1979) Social and evolutionary significance of social insect symbionts. Social Insects, 1: 339-413.

Leclerc, P. and Heurtault, J. (1979) Pseudoscorpions de l'Ardèche. Revue Arachnologique, 2(5): 239-247. 
Lewin, G.R., Johnson, A.L., Soto, R.D.M., Perry, K., Book, A.J., Horn, H.A., Pinto-Tomás, A.A. and Curie, C.R. (2016) Cellulose-enriched microbial communities from leaf-cutter ant (Atta colombica) refuse dumps vary in taxonomic composition and degradation ability. PLoS One, 11(3): e0151840. https: / / doi.org/10.1371/journal.pone.0151840

Martínez, R.J., Villegas - Guzmán, G.A., Quirós, D.I., Emmen, D. and Gaona, S. (2019)Nuevos datos de distribución geográfica de algunas especies de pseudoescorpiones (Arachnida: Pseudoscorpiones) del continente americano. Revista Ibérica de Aracnología, 35: 67-69.

Moser, I.C. (1963) Contents and structure of Atta texana nest in summer. Annals of the Entomological Society of America, 56: 286-291.

Muchmore, W.B. (1971) Phoresy by North and Central American pseudoscorpions. Proceedings of the Rochester Academy of Science, 12(2): 77-97.

Muchmore, W.B. (1991) The identity of Chelifer communis var. pennsylvanicus and description of a new species of Lustrochernes (Pseudoscorpionida: Chernetidae). Entomological News, 102(2): 79-89.

Newlands, G. (1978) Arachnida (except Acari). In: Biogeography and ecology of Southern Africa (pp. 685-702). Springer, Dordrecht.

Parmentier, T. (2016) Conflict and cooperation between ants and ant-associated arthropods [PhD thesis]. Leuven: University of Leuven.

Reyes-Castillo, P. and Hendrichs, J. (1975) Pseudoscorpiones asociados con pasálidos. Acta Politécnica Mexicana, 16: 129-133.

Rocha, F.H., Lachaud, J.P. and Pérez-Lachaud, G. (2020) Myrmecophilous organisms associated with colonies of the ponerine ant Neoponera villosa (Hymenoptera: Formicidae) nesting in Aechmea bracteata bromeliads: a biodiversity hotspot. Myrmecological News, 30: 73-92.

Rojas, P. (1989) Entomofauna asociada a los detritos de Atta mexicana (F. Smith) (Hymenoptera: Formicidae) en una Zona Árida del Centro de México. Acta Zoológica Mexicana, 33: 1-51.

Schmitz, O.J., Jones, H.P. and Barton, B.T. (2008) Scavengers. In (ed. Jorgensen S.E., and Fath B.), pp. 3160-3164. Elsevier B. V., Amsterdam, Netherlands.

Stahel, G. and Geijskes, D.C. (1939) Ueber den bau der nestervon Atta cephalotes L. und Atta sexdens L. (Hym. Formicidae). Revista de Entomologia, Rio de Janeiro, 10(1): 27-78.

Tizo-Pedroso, E. and Del-Claro, K. (2007) Cooperation in the neotropical pseudoscorpion, Paratemnoides nidificator (Balzan, 1888): feeding and dispersal behavior. Insectes Sociaux, 54: 124-131.

Torres, R., Bedoya Roqueme, E. and Tovar Marquéz, J. (2018) Cooperative foraging of Paratemnoides nidificator (Balzan, 1888) (Pseudoscorpiones: Atemnidae) on two species of ants (Hymenoptera: Formicidae) in the tropical dry Forest, Colombian Caribbean. Intropica, 14(1): 43-50. https:/ / doi.org/10.21676/23897864.2697

Weber, N.A. (1972) Gardening ants: the attines. Memoirs of the American Philosophical Society, vol. 92. Philadelphia: American Philosophical Society. 146 pp.

Wirth, W.W. and Marston, M. (1968) A method for mounting small insects on microscope slides in Canada balsam. Annals of the Entomological Society of America, 68: 783-784.

Zeh, D.W. and Zeh, J.A. (1991) Novel use of silk by the harlequin beetle-riding pseudoscorpion, Cordylochernes scorpioides (Pseudoscorpionida, Chernetidae). Journal of Arachnology, 19: 153-154.

Zeh, D.W. and Zeh, J.A. (1992) Dispersal-generated sexual selection in a beetle-riding pseudoscorpion. Behavioral Ecology and Sociobiology, 30: 135-142. 